\title{
PEMENUHAN HAK ANAK YANG TIDAK DIKETAHUI ASAL USULNYA DALAM MEMPEROLEH AKTA KELAHIRAN DI LEMBAGA KESEJAHTERAAN SOSIAL ANAK (Studi Pada SOS Children's Village Medan)
}

\author{
Nurhimmi Falahiyati ${ }^{1)}$, Akiruddin Ahmad ${ }^{2)}$ \\ Fakultas Hukum Universitas Al Washliyah Medan \\ Nurhimmi19@gmail.com
}

\begin{abstract}
Abstraksi
Setiap anak berhak atas nama sebagai identitas dirinya dan juga status kewarganegaraan yang merupakan hak dasar dan wajib diberikan negara kepadanya. Identitas diri setiap anak harus diberikan sejak kelahirannya dalam bentuk akta kelahiran. Muncul permasalahan ketika ditemukan anak yang tidak diketahui asal usul dan keluarganya, yang kemudian diasuh oleh Lembaga Kesejahteraan Sosial Anak. Bagaimana pemenuhan hak atas identitas anak tersebut dalam memperoleh akta kelahiran? Untuk mengetahui hal tersebut, maka dilakukan penelitian melalui pendekatan yuridis empiris yang bersifat kualitatif deskriptif dengan tujuan untuk menganalisa implementasi pemenuhan hak anak atas identitas yang diasuh di Lembaga Kesejahteraan Sosial Anak di Kota Medan. Penelitian dilakukan dengan mengkaji ketentuan hukum yang berlaku dan bagaimana kenyataannya di masyarakat, untuk kemudian dirumuskan secara kualitatif menjadi suatu hipotesis. Dari penelitian yang dilakukan, ditemukan bahwa masih belum terpenuhinya hak anak yang tidak diketahui asal usulnya yang kemudian diasuh di Lembaga Kesejahteraan Sosial Anak Kota Medan tersebut dalam memperoleh akta kelahiran. Hal ini disebabkan karena Lembaga Kesejahteraan Sosial Anak kesulitan melengkapi Berkas Berita Acara Pemeriksaan Kepolisian perihal penemuan anak yang diminta oleh Dinas Kependudukan dan Catatan Sipil Kota Medan sebagai salah satu persyaratan yang harus dilampirkan. Dinas kependudukan dan Catatan Sipil Kota Medan juga tidak memberikan solusi lain terhadap kekurangan berkas yang harus dilampirkan, sehingga hak anak akhirnya menjadi terabaikan.
\end{abstract}

Kata kunci: akta kelahiran, anak, Lembaga Kesejahteraan Sosial Anak.

\begin{abstract}
Every child has the right to a name as his identity and also citizenship status which is a basic right and must be given by the state to him. The identity of each child must be given from birth in the form of a birth certificate. Problems arise when children with unknown origins and their families are found, which is then taken care of by the Child Welfare Institution. What about fulfilling the right to the child's identity in obtaining a birth certificate? To find this out, the research was carried out through an empirical descriptive qualitative juridical approach with the aim to analyze the implementation of fulfilling children's rights to identity cared for at the Child Welfare Institution in Medan City. The research was conducted by reviewing the applicable legal provisions and how the reality is in society, to then be formulated qualitatively into a hypothesis. From the research conducted, it was found that the rights of children whose origins were not yet fulfilled were later fulfilled which were then raised in the Medan City Child Welfare Institution in obtaining a birth certificate. This is because the Child Welfare Institution has difficulty completing the Police Examination Minutes regarding the discovery of children requested by The Department of Population and Civil Registration of the Medan City as one of the requirements that must be attached. The Department of Population and Civil Registration of the Medan City also did not provide other solutions to the lack of files that must be attached, so that children's rights were eventually neglected.
\end{abstract}

Keyword: birth certificate, child, child welfare institution. 


\section{PENDAHULUAN}

Anak merupakan generasi penerus bangsa yang padanya melekat harkat, martabat dan hak-hak sebagai manusia yang harus dilindungi dan dijunjung tinggi. Salah satu hak anak yang paling vital dan wajib dipenuhi oleh negara adalah masalah hak sipil dan kebebasan. Berdasarkan temuan dari Komisi Perlindungan Anak Indonesia (KPAI) menunjukkan bahwa masih rendahnya penghormatan, pemenuhan dan perlindungan terkait hak sipil dan kebebasan anak. Beberapa permasalahan yang dominan dalam kerangka bidang sipil dan kebebasan anak yang selama ini terjadi antara lain hak atas nama dan kewarganegaraan, hak mempertahankan identitas, hak kebebasan menyatakan pendapat dan hak akses kepada informasi yang layak.

Hak atas nama dan kewarganegaraan merupakan hak dasar yang melekat pada setiap anak yang wajib diberikan negara. Hak atas nama diperlukan sebagai bentuk pengakuan dan bukti hukum bahwa seseorang itu ada, sementara kewarganegaraan merupakan alat bukti hukum bahwa anak tersebut adalah warga negara yang terkait dengan status, perlindungan dan hak serta kewajiban anak yang bersangkutan.

Undang-undang Nomor 23 Tahun 2002 tentang Perlindungan Anak memuat ketentuan dan prinsip Konvensi Hak-Hak Anak, salah satunya adalah hak anak atas identitas dirinya. Hak ini diperkuat dengan Undang-undang Nomor 23 Tahun 2006 tentang Administrasi Kependudukan, dimana setiap anak harus didaftarkan kelahirannya.

Hak atas identitas ini penting, karena apabila anak tidak memiliki akta kelahiran, maka dia tidak mempunyai status hukum atas dirinya, tidak mempunyai hak dasar, dan tidak punya status kewarganegaraan. Tanpa adanya akta kelahiran, anak tidak terdaftar di dalam Kartu Keluarga (KK). Bagaimana kemudian jaminan perlindungan kesehatannya, karena BPJS tidak bisa melayani tanpa adanya KK. Anak yang tidak mempunyai akta kelahiran juga sangat rentan terhadap resiko, diantaranya pemalsuan identitas dan tindak pidana perdagangan anak.

Permasalahan bertambah ketika anak yang lahir kemudian ditelantarkan orangtuanya, dan pada akhirnya diasuh oleh Lembaga Kesejahteraan Sosial Anak (LKSA). Siapa yang kemudian bertanggung jawab untuk pembuatan akta kelahiran anak-anak tersebut.

Berdasarkan data dari Badan Pusat Statistik, pada tahun 2019 anak berumur 017 tahun yang memiliki akta kelahiran di Indonesia sebesar $86,01 \%$, di Sumatera Utara persentasenya lebih kecil yaitu sebesar $76,81 \%$, bahkan terhadap anak Berumur 0-4 Tahun yang Memiliki Akta Kelahiran, Sumatera Utara masih diangka $58,06 \%$. Angka ini belum dipersempit ketika menyinggung masalah akta kelahiran anak yang tidak diketahui asal usul dan orangtuanya, yang kemudian diasuh oleh LKSA, dimana banyak LKSA yang merasa kesulitan dalam melengkapi akta kelahiran anak-anak tersebut. Kesulitannya bukan hanya dalam hal siapa yang bertanggung jawab dalam proses pengurusannya, namun juga terkendala dengan rendahnya pemahaman stake holder pengambil kebijakan dalam proses, prosedur dan syarat-syarat pencatatan kelahiran. Apabila hal ini terus dibiarkan, bagaimana kemudian anak-anak tersebut dapat menjadi generasi penerus bangsa yang potensial dan tangguh, sementara hak dasarnya saja untuk hidup saja tidak terpenuhi.

Berdasarkan hal-hal tersebut diatas maka penulis tertarik untuk mengkaji bagaimana pemenuhan hak anak yang tidak diketahui asal usulnya dalam memperoleh akta kelahiran pada anak yang diasuh di lembaga Kesejahteraan Sosial Anak (LKSA) di Kota Medan.

\section{METODE}

Penelitian ini merupakan penelitian yuridis empiris yang bersifat kualitatif deskriptif. Yaitu penelitian yang mengkaji ketentuan hukum yang berlaku serta apa 
yang sebenarnya terjadi di dalam masyarakat. Penelitian dilakukan secara deskriptif untuk memberikan gambaran akurat tentang fenomena yang sedang terjadi di masyarakat, untuk kemudian dirumuskan secara kualitatif menjadi suatu hipotesis. Tujuan penelitian adalah untuk menganalisa implementasi pemenuhan hak anak yang tidak diketahui asal usulnya dalam memperoleh akta kelahiran pada anak yang diasuh pada Lembaga Kesejahteraan Sosial Anak (LKSA) Kota Medan.

Sumber data penelitian ini menggunakan data primer dan data sekunder. Data primer diperoleh melalui langsung dari objek yang diteliti, yaitu melalui wawancara dan pengumpulan data yang dilakukan kepada SOS Children Village's Medan selaku Lembaga Kesejahteraan Sosial Anak di Kota Medan, Dinas Sosial Kota Medan, Pekerja Sosial Kemensos RI, dan Dinas Kependudukan dan Catatan Sipil Kota Medan. Data sekunder diperoleh melalui bahan hukum primer, sekunder dan tersier yang mendukung penelitian ini.

\section{HASIL DAN PEMBAHASAN}

Anak merupakan generasi penerus bangsa yang padanya melekat harkat, martabat dan hak-hak sebagai manusia yang harus dilindungi dan dijunjung tinggi, sehingga hak anak atas kelangsungan hidup, tumbuh kembang, berpartisipasi, perlindungan dari tindak kekerasan dan diskriminasi terus terjaga keutuhannya. Negara bersama masyarakat, keluarga dan orang tua secara bersama-sama bertanggung jawab terhadap kelangsungan hidup anak seutuhnya. Termasuk di dalamnya berkewajiban dan bertanggung jawab terhadap penyelenggaraan perlindungan anak, karena apabila dilihat dari sisi perkembangan fisik dan psikisnya, anak merupakan pribadi lemah yang belum bisa melindungi dan memenuhi semua kebutuhannya sendiri.

Sebagai salah satu bentuk perhatian pemerintah Indonesia terhadap hak-hak anak, Indonesia telah meratifikasi Konvensi Hak-hak Anak dengan Keputusan Presiden Nomor 36 Tahun 1990 tanggal 25 Agustus 1990 yang mulai diberlakukan di Indonesia tanggal 5 Oktober 1990. Convention on the Rights of the Child (CRC) atau Konvensi Hak Anak disetujui oleh Majelis Umum Perserikatan Bangsa-Bangsa (PBB) pada tanggal 20 November 1989. Konvensi ini merupakan instrumen internasional di bidang hak asasi manusia dengan cakupan hak yang paling komprehensif. $C R C$ terdiri dari 54 pasal yang hingga saat ini dikenal sebagai satu-satunya konvensi di bidang Hak Asasi Manusia khususnya bagi anakanak yang mencakup baik hak sipil dan politik maupun hak-hak ekonomi, sosial dan budaya.

Konvensi Hak Anak terdiri dari 54 pasal, secara garis besar mencakup tiga hal, yaitu:

1. Penegasan hak-hak anak, yakni menegaskan apa yang merupakan hak anak, seperti hak hidup, hak atas pendidikan, hak atas perlindungan dan lain-lain.

2. Perlindungan anak oleh negara, yakni menegaskan kewajiban dan tanggung jawab negara menjamin, menghormati, melindungi, dan memenuhi hak-hak anak.

3. Peran serta berbagai pihak (pemerintah, masyarakat, orang tua, dan swasta) dalam menjamin, menghormati, memenuhi, dan melindungi hak-hak anak.

Tindak lanjut dari ratifikasi tersebut, pada tanggal 22 Oktober 2002, Indonesia telah membuat Undang-Undang Nomor 23 Tahun 2002 tentang Perlindungan Anak. Undang-Undang Nomor 23 Tahun 2002 tentang Perlindungan Anak dalam perjalanannya mengalami perubahan. Kemudian terbit Undang-undang Nomor 35 tahun 2014 tentang Perubahan Atas Undang-Undang Nomor 23 tahun 2002 tentang Perlindungan Anak. Perubahan Undang-undang Perlindungan Anak disebabkan karena untuk meningkatkan perlindungan terhadap anak perlu dilakukan 
penyesuaian terhadap beberapa ketentuan dalam Undang-Undang Nomor 23 Tahun 2002 tentang Perlindungan Anak. Undangundang ini kemudian diubah lagi dengan keluarnya perubahan kedua atas UndangUndang Nomor 23 Tahun 2002 Tentang Perlindungan Anak Nomor 17 Tahun 2016. Keseluruhan undang-undang ini selanjutnya disebut dengan UndangUndang Perlindungan Anak.

Pasal 1 angka 1 Undang-Undang Perlindungan Anak menyebutkan bahwa anak adalah seseorang yang belum berusia 18 tahun, termasuk di dalamnya anak yang masih dalam kandungan. Pasal 1 angka 12 menyebutkan bahwa Hak Anak adalah bagian dari hak asasi manusia yang wajib dijamin, dilindungi, dan dipenuhi oleh Orang Tua, Keluarga, masyarakat, negara, pemerintah, dan pemerintah daerah.

Diantara hak-hak anak yang mendasar yang diatur dalam Undang-Undang Perlindungan Anak yaitu hak memperoleh suatu nama dan status kewarganegaraan sebagaimana termuat dalam Pasal 5. Identitas diri merupakan hak yang harus diperoleh bagi anak yang harus dijalankan oleh pemerintah. Identitas dimaksud dituangkan dalam akta kelahiran sebagaimana dinyatakan dalam Pasal 27 dan 28 Undang-Undang Perlindungan Anak. Hal ini sejalan dengan Convention on the Rights of the Child (CRC) yang secara spesifik mengatur kebutuhan anak menjadi acuan yuridis untuk menganalisis persoalan ini. Pasal 7 C menyatakan anak didaftarkan segera setelah kelahiran dan berhak memperoleh kewarganegaraan. Selanjutnya Pasal 8 menegaskan bahwa negara menghormati hak anak atas kewarganegaraannya.

Temuan dra. Latifah Iskandar, salah satu komisioner Komisi Perlindungan Anak Indonesia (KPAI) bidang hak sipil dan kebebasan sebagaimana yang dimuat di laman kpai.go.id, bahwa masih rendahnya penghormatan, pemenuhan, dan perlindungan terkait hak sipil dan kebebasan anak. Masalah dominan yang selama ini terjadi meliputi hak nama dan kewarganegaraan, hak mempertahankan identitas, hak kebebasan menyatakan pendapat, dan hak akses kepada informasi yang layak. Salah satu upaya dalam pemenuhan hak sipil anak adalah dengan melakukan pencatatan kelahirannya.

Pencatatan kelahiran sebagaimana telah diatur dalam pasal 27 dan 28 Undangundang perlindungan anak, wajib diterbitkan paling lama 30 (tiga puluh) hari sejak dipenuhinya semua persyaratan yang dibutuhkan. Hal ini diperkuat dengan Undang-Undang nomor 23 tahun 2006 dan direvisi dengan Undang-Undang nomor 24 tahun 2013 tentang administrasi kependudukan (untuk selanjutnya disebut dengan Undang-Undang Administrasi Kependudukan), dimana dalam pasal 27 mengatur setiap kelahiran wajib dilaporkan paling lama 60 (enam puluh) hari sejak kelahiran.

Pelaporan setiap peristiwa kependudukan dan peristiwa penting yang terjadi merupakan kewajiban setiap penduduk. Peristiwa Kependudukan adalah kejadian yang dialami Penduduk yang harus dilaporkan karena membawa akibat terhadap penerbitan atau perubahan Kartu Keluarga, Kartu Tanda Penduduk dan/atau surat keterangan kependudukan lainnya meliputi pindah datang, perubahan alamat, serta status tinggal terbatas menjadi tinggal tetap. Sedangkan Peristiwa Penting adalah kejadian yang dialami oleh seseorang meliputi kelahiran, kematian, lahir mati, perkawinan, perceraian, pengakuan anak, pengesahan anak, pengangkatan anak, perubahan nama dan perubahan status kewarganegaraan.

Terkait dengan terjadinya peristiwa penting terhadap anak, semisal terjadinya kelahiran, tentunya pelaporan tidak dapat dilakukan oleh dirinya sendiri. Yang berkewajiban dan bertanggung jawab atas pendaftaran kelahiran anak adalah orang tuanya. Dalam hal orang tua tidak ada, atau tidak diketahui keberadaannya, atau karena suatu sebab tidak dapat melaksanakan kewajiban dan tanggung jawabnya, maka kewajiban dan tanggung jawab tersebut 
dapat beralih kepada keluarganya. Kemudian timbul persoalan lagi misalnya anak tersebut dibuang di jalan ataupun ditinggalkan begitu saja setelah dilahirkan, sehingga tidak diketahui keberadaan dari orang tua dan keluarganya sama sekali, siapa yang kemudian bertanggung jawab dan berkewajiban dalam penyelenggaraan perlindungan anak, termasuk dalam pemenuhan hak sipilnya, terutama dalam pembuatan akta lahirnya.

Sesuai dengan Pasal 20 UndangUndang Perlindungan Anak, disebutkan bahwa Negara, Pemerintah, Pemerintah Daerah, Masyarakat, Keluarga, dan Orang Tua atau Wali berkewajiban dan bertanggung jawab terhadap penyelenggaraan Perlindungan Anak. Pasal 34 ayat (1) UUD 1945 juga mengamanatkan kewajiban negara untuk memelihara fakir miskin dan anak terlantar. Bagi fakir miskin dan anak terlantar, Pemerintah dan pemerintah daerah memberikan rehabilitasi sosial, jaminan sosial, pemberdayaan sosial, dan perlindungan sosial sebagai perwujudan pelaksanaan kewajiban negara dalam menjamin terpenuhinya hak atas kebutuhan dasar warga negara yang miskin dan tidak mampu.

Terhadap anak-anak yang dibuang dan ditelantarkan oleh orang tuanya, biasanya akan diasuh oleh Lembaga Kesejahteraan Sosial Anak (LKSA) atas rujukan dari Dinas Sosial. Ketika ada anak yang ditelantarkan orang tuanya tanpa adanya identitas, anak tersebut diantarkan ke Kepolisian setempat baik oleh orang yang menemukan ataupun oleh Kepala Lingkungan(RT)/Kelurahan setempat, apabila dirasa perlu untuk diperiksakan kesehatannya terlebih dahulu, maka anak tersebut dirujuk ke puskesmas atau rumah sakit terdekat. Setelah itu dibuat laporan dan berita acara pemeriksaan oleh kepolisian yang dibuat oleh pihak yang menemukan atau dari puskesmas/rumah sakit. Kemudian anak diserahkan kepolisian ke Dinas Sosial, dan sembari mencari siapa orang tua dan keluarga dari anak tersebut, baik dengan pengumuman lewat media ataupun penelusuran manual yang dilakukan kelurahan setempat dan kepolisian, Dinas Sosial menitipkan anak tersebut ke LKSA dengan menyerahkan Berita Acara Pemeriksaan dari Kepolisian, Berita Acara Serah Terima dari puskesmas ke Dinas Sosial, dan Berita Acara Serah Terima Anak dari Dinas Sosial ke LKSA.

Lembaga Kesejahteraan Sosial Anak (LKSA) dahulunya disebut dengan Panti Sosial Asuhan Anak. Setelah keluarnya Peraturan Menteri Sosial Republik Indonesia Nomor 30/Huk/2011 tentang Standar Nasional Pengasuhan Anak Untuk Lembaga Kesejahteraan Sosial Anak, istilah Panti Sosial Asuhan Anak dirubah menjadi Lembaga Kesejahteraan Sosial Anak.

Lembaga Kesejahteraan Sosial Anak (LKSA) berperan sebagai alternatif terakhir pengasuhan anak bagi anak-anak yang dibuang dan ditelantarkan orang tuanya tanpa dapat diketahui identitas dan asal usulnya. Salah satu Standar Nasional Pengasuhan Anak melalui Lembaga Kesejahteraan Sosial Anak ini adalah terpenuhinya semua aspek hak anak baik kebutuhan dasar, pengasuhan anak, perlindungan maupun aspirasi anak. Lembaga Kesejahteraan Sosial Anak harus berperan sebagai pengganti orang tua untuk sementara bagi anak-anak yang ditempatkan di Lembaga Kesejahteraan Sosial Anak, dan bertanggung jawab untuk memenuhi pemenuhan hak-hak mereka. Lembaga Kesejahteraan Sosial Anak harus memastikan bahwa setiap anak harus mempunyai identitas legal yang jelas, termasuk akta kelahiran dan KTP.

Kasus anak yang dibuang dan ditelantarkan di Kota Medan pertama kali terjadi di tahun 2016, dimana anak tersebut kemudian diserahkan Dinas sosial Kota Medan ke LKSA SOS Children's Village Medan. Sejak saat itu sampai dengan sekarang SOS Chlidren Village's Medan telah menerima dan mengasuh 8 orang anak yang tidak diketahui asal usulnya, yang terdiri dari 7 orang anak laki-laki dan 1 
orang anak perempuan, dari total 99 orang anak yang diasuhnya.

Dari keseluruhan 8 orang anak tanpa identitas yang diasuh di SOS Children Village's Medan tersebut, belum satupun anak yang memiliki akta kelahiran. Penerbitan akta lahir ini terkendala karena kurangnya kelengkapan berkas yang disyaratkan oleh Dinas Kependudukan dan Catatan Sipil Kota Medan, yaitu Berita Acara Pemeriksaan oleh Kepolisian.

Dalam hal pembuatan akta kelahiran terhadap anak yang tidak diketahui identitasnya, Undang-Undang Nomor 35 Tahun 2014 Tentang Perubahan Atas Undang-Undang Nomor 23 Tahun 2002 Tentang Perlindungan Anak, mensyaratkan adanya keterangan orang yang menemukan dan dilengkapi dengan Berita Acara Pemeriksaan oleh Kepolisian. Sebelumnya, di Undang-Undang Nomor 23 Tahun 2002 Tentang Perlindungan Anak hanya didasarkan pada keterangan yang diberikan oleh orang yang menemukan anak tersebut. Kemudian keluar Undang-Undang Nomor 23 Tahun 2006 Tentang Administrasi Kependudukan, di Pasal 28 menyebutkan pencatatan kelahiran dalam Register Akta Kelahiran dan penerbitan Kutipan Akta Kelahiran terhadap peristiwa kelahiran seseorang yang tidak diketahui asal-usulnya atau keberadaan orang tuanya, didasarkan pada laporan orang yang menemukan dilengkapi Berita Acara Pemeriksaan dari kepolisian. Ketika terjadi perubahan Undang-Undang Perlindungan Anak di tahun 2014, persyaratan pembuatan akta kelahiran juga ikut disesuaikan dengan melampirkan Berita Acara Pemeriksaan dari Kepolisian.

Secara rinci, upaya pemerintah dalam memenuhi hak anak atas identitasnya diatur dalam Pasal 3 Peraturan Menteri Dalam Negeri Nomor 9 Tahun 2016 Tentang Percepatan Peningkatan Cakupan Kepemilikan Akta Kelahiran. Di dalam Permendagri ini diatur syarat-syarat pencatatan kelahiran adalah:

1. Surat keterangan lahir dari dokter/bidan/penolong kelahiran
2. Akta nikah/kutipan akta perkawinan

3. Kartu keluarga

4. KTP-el orangtua/wali/pelapor, atau

5. Paspor bagi WNI bukan penduduk dan orang asing.

Terhadap anak yang tidak diketahui asal usulnya atau keberadaan orang tuanya, dilakukan dengan :

1. Melampirkan Berita Acara Pemeriksaan dari kepolisian, atau

2. Menggunakan Surat Pernyataan Tanggung Jawab Mutlak (SPTJM) Kebenaran Data Kelahiran yang ditandatangani oleh wali/ penanggung jawab.

SPTJM kebenaran data kelahiran adalah pernyataan yang dibuat oleh orang tua/ wali/ pemohon dengan tanggung jawab penuh atas kebenaran data kelahiran seseorang, dengan diketahui oleh dua orang saksi.

Namun pada tanggal 18 oktober 2018 keluar Peraturan Presiden Republik Indonesia Nomor 96 Tahun 2018 Tentang Persyaratan Dan Tata Cara Pendaftaran Penduduk Dan Pencatatan Sipil, dimana pada pasal 33 ayat 2 dan 3 mensyaratkan pendaftaran anak yang tidak diketahui asal usulnya harus memiliki Berita Acara Pemeriksaan dari Kepolisian dan juga SPTJM yang diketahui oleh 2 orang saksi. Hal ini tentu membuat rancu lagi proses pendaftaran di lapangan, karena sebelumnya, peraturan yang ada cukup mensyaratkan salah satu saja yang dipenuhi, berita acara Pemeriksaan oleh kepolisian atau SPTJM yang ditandatangani wali/penanggung jawab.

Dalam proses pembuatan akta kelahiran di Dinas kependudukan dan Catatan Sipil Kota Medan, dapat dilakukan secara online ataupun manual dengan datang langsung ke loket pendaftaran dengan melampirkan berkas persyaratan yang diminta. Apabila pendaftaran dilakukan secara online, dapat login ke website www.sibisa.pemkomedan.go.id dengan menggunakan email yang valid, 
kemudian mengisi form permohonan dengan lengkap, kemudian submit dan mencetak bukti pendaftaran. Syarat pembuatan akta kelahiran baik secara manual ataupun online adalah fotokopi KTP orang tua, Foto kopi Kartu keluarga, fotokopi surat kelahiran dari dokter atau bidan, fotokopi buku nikah dan fotokopi data identitas saksi. Biasanya jangka waktu yang dibutuhkan dalam mengurus pembuatan akta kelahiran adalah 4 hari. Apabila didaftarkan dalam jangka waktu 60 hari setelah kelahiran, maka tidak akan dipungut biaya apapun alias gratis, namun apabila didaftarkan setelah 60 kelahiran, maka akan dikenakan denda keterlambatan sebesar Rp. 10.000,- (sepuluh ribu rupiah).

Akta kelahiran terhadap anak yang tidak diketahui asal usul dan identitasnya juga dapat didaftarkan baik secara manual ke loket pendaftaran maupun secara online melalui website, asalkan semua persyaratan yang diminta terpenuhi. Dinas Kependudukan Dan Catatan Sipil Kota Medan mensyaratkan untuk dapat mendaftarkan kelahiran anak yang tidak diketahui asal usul dan identitasnya selain dengan melampirkan KK dan KTP pemohon, juga dengan Berita Acara Pemeriksaan dari Kepolisian dan SPTJM Kebenaran Data Kelahiran yang diketahui oleh dua orang saksi sesuai dengan yang disyaratkan oleh Peraturan Presiden Republik Indonesia Nomor 96 Tahun 2018 Tentang Persyaratan Dan Tata Cara Pendaftaran Penduduk Dan Pencatatan Sipil.

Permasalahan terkait kurangnya kelengkapan persyaratan berkas Berita acara Pemeriksaan dari Kepolisian perihal penemuan anak disebabkan karena tidak adanya laporan dari pihak yang menemukan anak tersebut ke Kepolisian, sehingga ketika anak tersebut telah sampai di tangan Dinas Sosial Kota Medan, Berita Acara Pemeriksaan tersebut tidak ada. Sekiranya pun ada surat yang dikeluarkan oleh Kepolisian, hanya berupa Surat Keterangan Penemuan Bayi/Anak Terlantar, namun surat ini tidak berlaku sebagai salah satu syarat diperolehnya akta lahir bagi anak terlantar tanpa identitas, karena yang diminta adalah BAP oleh Kepolisian.

Berdasarkan pasal 75 ayat (1) Undang-Undang Nomor 8 Tahun 1981 Tentang Hukum Acara Pidana, berita acara dibuat salah satunya adalah untuk tindakan pemeriksaan saksi. Pemeriksaan dilakukan penyidik terhadap saksi dengan tujuan mendapatkan keterangan yang dituangkan dalam BAP, guna membuat terang perkara sehingga peran seseorang maupun barang bukti dalam peristiwa pidana yang terjadi menjadi jelas. Pemeriksaan yang dituangkan dalam BAP ini ditandatangani oleh penyidik yang melakukan pemeriksaan dan orang yang diperiksa. Dengan demikian, tentu Kepolisian tidak dapat mengeluarkan Berita Acara Pemeriksaan tanpa adanya laporan dari pihak yang menemukan untuk kemudian diperiksa menjadi saksi.

Biasanya ketika terjadi penemuan anak, masyarakat yang menemukan akan melaporkannya ke Kepala Lingkungan (RT) atau Kelurahan setempat dan ke Kepolisian. Disini dibutuhkan peran aktif masyarakat untuk ikut bertanggung jawab terhadap penyelenggaraan perlindungan anak dengan langsung melaporkannya ke Kepolisian sekaligus membuat berita acaranya. Namun hal tersebut tidak terlaksana, entah karena stigma masyarakat yang negatif ketika harus berurusan dengan Kepolisian, ataupun karena kurang pengetahuannya tentang apa yang harus dilakukan ketika terjadi peristiwa tersebut.

Terhadap tidak dapatnya dipenuhi Berita Acara Pemeriksaan oleh Kepolisian, telah dilakukan rapat koordinasi antara Dinas Kependudukan dan Catatan Sipil Kota Medan, Dinas Sosial Kota Medan, Pekerja Sosial Kementrian Sosial RI, LKSA Kota Medan, Kepolisian dan DPD RI. Namun pertemuan ini tidak membuahkan hasil yang siginifikan dikarenakan pihak yang hadir di rapat ini bukanlah pengambil kebijakan langsung di instansinya, sehingga tidak berdampak 
besar dan tidak ada keputusan yang diambil dan dapat dijalankan sebagai jalan keluar.

Permasalahan ini memerlukan campur tangan pemerintah ketika peran serta masyarakat untuk melaporkan kejadian itu tidak terlaksana. Sekiranya tidak ada campur tangan pemerintah ketika pelaporan itu tidak dilaksanakan oleh masyarakat yang menemukan, maka perlindungan anak atas hak sipilnya akan terabaikan.

Tanggung jawab itu bisa saja diambil alih oleh Kepala Lingkungan atau Kelurahan setempat, ataupun Dinas Sosial dan Pekerja Sosial sebagai pelapor penemuan anak tersebut. Hal ini dikarenakan sungguh tidak mungkin lagi mencari siapa orang yang menemukan anak tersebut pertama kalinya. LKSA sebagai pihak terakhir dalam pengasuhan juga sebaiknya ketika menerima anak tanpa identitas dan tidak diketahui asal usulnya, meminta secara lengkap semua berkas yang diperlukan ketika penyerahan anak, yaitu Berita Acara Pemeriksaan dari Kepolisian, Berita Acara Serah Terima dari puskesmas ke Dinas Sosial, dan Berita Acara Serah Terima Anak dari Dinas Sosial ke LKSA, sehingga tidak akan terkendala lagi dalam pengajuan permohonan pembuatan akta lahirnya. Pada dasarnya SOS children's Village Medan telah melakukan berbagai upaya untuk dalam pemenuhan hak sipil anak-anak asuhnya, termasuk dalam pembuatan akta lahir anak yang tidak diketahui asal usulnya. Diantaranya dengan melakukan berbagai koordinasi dengan semua pihak yang terkait, termasuk di dalamnya KPAI, namun masih belum ditemukan jalan keluar dari kekurangan berkas tersebut. Karena itulah sebaiknya semua kelengkapan berkas dipenuhi ketika penyerahan anak, sehingga kekurangan berkas tersebut tidak menjadi masalah yang berlarut-larut.

Disisi lain, Dinas Kependudukan Dan Catatan Sipil Kota Medan juga selayaknya mencari jalan apabila ada kasus-kasus penemuan anak yang tidak lengkap persyaratannya dalam proses permohonan pembuatan akta lahir, terlebih terhadap anak-anak yang ditemukan beberapa tahun yang lalu yang tidak mungkin lagi dapat dibuatkan Berita Acara Pemeriksaan Kepolisiannya. Agar anak-anak yang tidak diketahi asal usul dan identitasnya ini dapat bersekolah dan memiliki identitas kependudukan, Dinas Kependudukan dan Catatan Sipil Kota Medan membolehkan anak-anak tersebut diurus Kartu Keluarga global dari LKSA dan diberikan NIK atau Nomor Induk Kependudukannya, namun karena belum dipenuhinya syarat dilampirkannya Berita Acara Pemeriksaan oleh Kepolisian, Dinas Kependudukan dan Catatan Sipil Kota Medan tidak dapat menerbitkan akta kelahirannya. Pasal 25 Undang-Undang Administrasi Kependudukan menyebutkan bahwa Instansi Pelaksana dalam hal ini Dinas Kependudukan Dan Catatan Sipil Kota Medan wajib melakukan pendataan penduduk rentan administrasi kependudukan yang salah satunya meliputi orang terlantar. Orang terlantar adalah adalah penduduk yang karena suatu sebab sehingga tidak dapat memenuhi kebutuhannya secara wajar, baik rohani, jasmani maupun sosial. Ciri-cirinya adalah tidak terpenuhinya kebutuhan dasar hidup khususnya makan, sandang dan papan, tempat tinggal tidak tetap/gelandangan, tidak mempunyai pekerjaan/kegiatan yang tetap, dan miskin. Lebih jauh pasal 13 Peraturan Menteri Dalam Negeri Republik Indonesia Nomor 96 tahun 2019 tentang Pendataan Dan Penerbitan Dokumen Kependudukan Bagi Penduduk Rentan Administrasi Kependudukan, menyebutkan bahwa pendataan dan penerbitan dokumen kependudukan bagi Penduduk rentan administrasi kependudukan dilakukan dengan mendatangi salah satunya panti asuhan bersama dengan perangka daerah terkait. Dalam hal ini seyogyanya Dinas Kependudukan Dan Catatan Sipil Kota Medan turut pro aktif dalam upaya pemenuhan hak anak terlantar tersebut. 


\section{KESIMPULAN}

Sebagaimana hak asasi yang dimiliki orang dewasa, anak mempunyai hak yang bersifat asasi dan telah dituangkan dalam Konvensi hak anak (Convention on the Rights of the Child) yang salah satunya perlidungan terhadap hak sipil anak, yaitu hak atas identitas dan kewarganegaraan yang dibuktikan dengan akta kelahiran. Secara umum, terhadap anak yang mempunyai orang tua sebagian besar telah terpenuhi haknya atas identitas, namun terhadap anak yang tidak diketahui identitasnya, timbul beberapa masalah sehingga akta kelahirannya masih terkendala untuk diproses. Hal ini disebabkan karena kurangnya kelengkapan berkas Berita Acara Pemeriksaan dari Kepolisian, sementara Berita Acara Pemeriksaan dari Kepolisian adalah hal mutlak yang harus dilampirkan dalam proses pengajuan permohonan pendaftaran anak. Untuk itu diperlukan turut campur pemerintah dalam mengisi kekosongan tersebut, baik itu dari pemerintah setempat tempat ditemukannya anak, Dinas Sosial Kota Medan , Dinas Kependudukan dan Catatan Sipil Kota Medan, dan Kepolisian. Apabila berbagai pihak ini tidak mencari jalan keluar dari tidak lengkapnya persyaratan yang dibutuhkan, maka dapat dipastikan anak-anak tanpa identitas yang tidak diketahui asal usulnya tidak akan terpenuhi hak asasinya sebagai manusia.

\section{DAFTAR PUSTAKA}

Undang-Undang Nomor 23 Tahun 2002 Tentang Perlindungan Anak.

Undang-Undang Nomor 35 Tahun 2014 Tentang Perubahan Atas UndangUndang Nomor 23 Tahun 2002 tentang Perlindungan Anak

Undang-Undang Nomor 17 Tahun 2016 Tentang Penetapan Peraturan Pemerintah Pengganti Undang-Undang Nomor 1 Tahun 2016 Tentang Perubahan Kedua Atas UndangUndang Nomor 23 Tahun 2002
Tentang Perlindungan Anak Menjadi undang-undang

Undang-Undang Nomor 23 Tahun 2006 Tentang Administrasi Kependudukan

Undang-Undang Nomor 24 Tahun 2013 Tentang Perubahan Atas UndangUndang Nomor 23 Tahun 2006 Tentang Administrasi Kependudukan

Peraturan Menteri Dalam Negeri Republik Indonesia Nomor 96 Tahun 2019 Tentang Pendataan Dan Penerbitan Dokumen Kependudukan Bagi Penduduk Rentan Administrasi Kependudukan

Peraturan Menteri Sosial Republik Indonesia Nomor 30/Huk/2011 Tentang Standar Nasional Pengasuhan Anak Untuk Lembaga Kesejahteraan Sosial Anak

Peraturan Pemerintah Republik Indonesia Nomor 40 Tahun 2019 Tentang Pelaksanaan Undang-Undang Nomor 23 Tahun 2006 Tentang Administrasi Kependudukan Sebagaimana Telah Diubah Dengan Undang-Undang Nomor 24 Tahun 2oi3 Tentang Perubahan Atas Undang Undang Nomor 23 Tahun 2006 Tentang Administrasi Kependudukan

Peraturan Presiden Republik Indonesia Nomor 96 Tahun 2018 Tentang Persyaratan Dan Tata Cara Pendaftaran Penduduk Dan Pencatatan Sipil

Peraturan Menteri Dalam Negeri Republik Indonesia Nomor 9 Tahun 2016 Tentang Percepatan Peningkatan Cakupan Kepemilikan Akta Kelahiran

Peraturan Menteri Dalam Negeri Republik Indonesia Nomor 108 Tahun 2019 Tentang Peraturan Pelaksanaan Peraturan Presiden Nomor 96 Tahun 2018 Tentang Persyaratan Dan Tata Cara Pendaftaran Penduduk Dan Pencatatan Sipil

Peraturan Menteri Dalam Negeri Republik Indonesia Nomor 19 Tahun 2018 Tentang Peningkatan Kualitas Layanan Administrasi Kependudukan

Peraturan Kepala Kepolisian Republik Indonesia Nomor 14 Tahun 2012 
Tentang Manajemen Penyidikan Tindak Pidana.

Undang-Undang Nomor 8 Tahun 1981 Tentang Hukum Acara Pidana

Badan Pusat Statistik, 2019, Persentase Anak Berumur 0-17 Tahun yang Memiliki Akta Kelahiran Menurut Provinsi (Persen), 2017-2019, diakses pada 27 juli 2020 , tersedia pada https://www.bps.go.id/indicator/12/14 12/1/ persentase-anak-yang-memilikiakta-kelahiran-menurut-provinsi.html

Badan Pusat Statistik, 2019, Persentase Anak Berumur 0-4 Tahun yang Memiliki Akta Kelahiran Menurut Provinsi (Persen), 2017-2019, diakses pada 27 juli 2020, tersedia pada https://www.bps.go.id/indicator/12/18 27/1/ persentase-anak-berumur-0-4tahun-yang-memiliki-akta-kelahiranmenurut-provinsi.html

Muladi (2005). Hak Asasi Manusia, Hakekat, Konsep Dan Implikasinya Dalam Perspektif Hukum Dan Mayarakat. Bandung: Refika Aditama. Hadiwijoyo,Suryo Sakti (2015). Pangarusatamaan Hak Anak Dalam Anggaran Publik. Yogyakarta : Graha Ilmu.

Nasution, Adnan Buyung, A Patra M.Zen (2006). Instrumen Internasional Pokok Hak Asasi Manusia. Jakarta : Yayasan Obor Indonesia.

Sbbkab.go.id, 2106, Urus Dokumen Kependudukan, Gratis, diakses pada 13 agustus 2020, tersedia pada http://sbbkab.go.id/urus-dokumenkependudukan-gratis/

Peraturan Menteri Sosial Republik Indonesia Nomor 30/Huk/2011 tentang Standar Nasional Pengasuhan Anak Untuk Lembaga Kesejahteraan Sosial Anak

Adi,Rianto (2010). Metodologi Penelitian Sosial Dan Hukum. Jakarta: Granit.

Susanti,Dyah Ochtorina, A'an Efendi (2014). Penelitian Hukum (Legal Research). Jakarta : Sinar Grafika.

Latifah Iskandar, Pemenuhan Hak Anak Atas Akta Kelahiran Merupakan Bagian Dari
Hak Sipil Yang Harus Dilindungi Konstitusi, diakses pada 27 Juli 2020, https://www.kpai.go.id/berita/artikel/p emenuhan-hak-anak-atas-akta-

kelahiran-merupakan-bagian-dari-haksipil-yang-harus-dilindungi-konstitusi

Murni, Djulaeka, (2019), Perlindungan atas Hak Anak yang Terabaikan (Studi Kasus Yayasan Anak Yatim di Surabaya), Jurnal Pamator volume 12 nomor

https://journal.trunojoyo.ac.id/pamator /article/view/5179/3502

Arlianti Imaria Simanjutak, (2012), Jaminan Hukum Terhadap Hak Memperoleh Akta Kelahiran Bagi Anak Panti Asuhan, Unnes Law Journal, 1(1)(2012), https://journal.unnes.ac.id/sju/index.ph $\mathrm{p} / \mathrm{ulj} /$ article/view/184/283

Taufan Alwany, (2020), Strategi Dinas Kependudukan Dan Pencatatan Sipil Dalam Pelayanan Kepemilikan Akta Kelahiran Bagi Anak-Anak Panti Asuhan Di Kota Makasar, Jurnal Ilmu Pemerintahan Suara Khatulistiwa (JIPSK), vol 5, no. 1, http://ejournal.ipdn.ac.id/khatulistiwa/ article/view/1124 